\title{
LIDAR MEASUREMENTS OF CANADIAN FOREST FIRE SMOKE EPISODE OBSERVED IN JULY 2013 OVER WARSAW, POLAND
}

\author{
Lucja Janicka $^{1}$ *, Iwona S. Stachlewska ${ }^{1}$, Krzysztof M. Markowicz ${ }^{1}$, Holger Baars ${ }^{2}$, \\ Ronny Engelmann ${ }^{2}$ and Birgit Heese ${ }^{2}$ \\ ${ }^{1}$ Institute of Geophysics, Faculty of Physics, University of Warsaw (IGFUW), Pasteura 7, \\ 02-093 Warsaw, Poland, *Email: lucja.janicka@student.uw.edu.pl \\ ${ }^{2}$ Leibniz Institute for Tropospheric Research, Leipzig, Germany
}

\begin{abstract}
This paper presents a preliminary study of aerosol optical properties of air-mass advected on $10^{\text {th }}$ July 2013 from Canada above Warsaw, Poland, during the forest fire event that occurred in Quebec at the beginning of July 2013. The observations were conducted with use of the modern version of 8-channel Polly ${ }^{\mathrm{XT}}$ lidar capable of measuring at $3 \beta+2 \alpha+2 \delta+\mathrm{VW}$ and interpreted with available information from the MACC model, the CALIPSO and MODIS satellite sensors, the AERONET data products and the data gathered within the Poland-AOD network.
\end{abstract}

\section{INTRODUCTION}

Biomass burning aerosols released into the atmosphere during wildfires events have a significant impact on climate [1]. Smoke particles are composed mainly of organic carbon and black carbon which efficiently scatter and absorb solar radiation. Biomass smoke particles can act also as convenient cloud nuclei. Smoke properties depend on variety of factors such as a fuel type, moisture, combustion phase, or wind direction. Properties of biomass burning aerosols change rapidly with time. In comparison to the fresh smoke, larger size and more spherical shape of the aged smoke particles are observed. Favorable weather conditions can spread contaminants on a large area what can cause a worldwide influence on the radiative transfer.

In this study we focus on the long-range transported Canadian biomass burning smoke, that reached and was observed over Warsaw between 8-10 July 2013. Summer 2013, was the driest one in the past 40 years in Quebec, Canada. Thunderstorms in May 2013 caused ignition which finally led to great forest fires in July 2013, when over $2800 \mathrm{~km} 2$ of boreal forests were burned.

The event was observed, among others, by the multi-wavelength depolarization-Raman lidar located at the Radiative Transfer Laboratory (RTLab) in Warsaw, Poland. Here, we discuss some of the mentioned above observations.

\section{METHODOLOGY}

The Radiative Transfer Laboratory (RT-Lab) of the Institute of Geophysics, Faculty of Physics, University of Warsaw is part of the Poland-AOD research network (http://www.polandaod.pl). Measurements of the optical properties of aerosols, along with determination of related to them radiative effects in the troposphere are the main tasks of the laboratory. At the end of June 2013 measurement station was enriched by an installation of the automated multi-wavelengthRaman-polarization lidar of a Polly ${ }^{\mathrm{XT}}$ type [2]. The lidar started operating in the first week of July 2013, thus the advection of air masses containing smoke from Canadian fires was the first major event observed by the lidar.

In the first step lidar measurements were used to estimate altitudes of aerosol layers that could possibly contain biomass burning aerosols. This information was used as an input to calculate airmass backward trajectories using the HYSPLIT trajectory model [3].

Optical properties (backscatter and extinction coefficients, lidar ratios, depolarization ratios) were retrieved using standard approaches applied at the lidar sites of EARLINET [4]. 
The particle backscatter coefficient profiles at $355,532 \mathrm{~nm}$ and the particle extinction profiles at 355 and $532 \mathrm{~nm}$ were obtained independently using Raman channels [5]. If it is not possible to use it, the assumption of the lidar ratio is taken [6], [7]. Also the calibrated depolarization profiles at 355 and $532 \mathrm{~nm}$ were calculated [8]. In the near future, we plan to perform also the retrieval of micro-physical properties of aerosols for characteristic layers found for different periods of the event [9].

Finally, the data were interpreted with other available means: the model MACC, the CALIPSO and MODIS satellite sensors, the AERONET data products and using the data gathered within the Poland-AOD network [10].

\section{RESULTS}

An aerosol layer is visible at a height of about 2.5 $\mathrm{km}$ from the beginning of measurements at 08:30UTC on 8 July 2013 to 05:00 UTC on 10 July 2013 (not shown here; quicklooks of the signals are available via the Polly ${ }^{\mathrm{XT}}$ Net Website at $h t t p: / / p o l l y . t r o p o s . d e$ ). For this period, six-days backward trajectories indicate inflow from over Canada that was uniform at all altitudes. Thus, we assume that this layer contained biomass burning aerosols. From about 18:00 UTC on 8 July to 06:00UTC on 9 July there is visible increased backscattered signal, especially at $1064 \mathrm{~nm}$, at this height. It is probable that the biomass burning aerosol served as cloud condensation nuclei for the clouds that formed at $2.5 \mathrm{~km}$.

From 12:00 UTC on 10 July, aerosol layers appear at higher levels. Optical properties were calculated using averaged data from 18:45 UTC to until 19:45 UTC on that day. Fig. 1. shows the temporal development of the range-corrected signal at $1064 \mathrm{~nm}$. Aerosol layers at about 3 and 5 $\mathrm{km}$ are clearly visible. At a height of about $1.5 \mathrm{~km}$, clouds associated with the weather front began to form.

Backscatter and extinction coefficient profiles up to $7 \mathrm{~km}$ are shown in Fig. 2. At altitudes of circa $1.5 \mathrm{~km}, 3 \mathrm{~km}$ and $5.5 \mathrm{~km}$ three aerosol layers are discernible. The lowest one likely reflects boundary layer and cloud layer forming a weather front. The other two are likely to be due to the advection of air-masses containing aerosols. Maximum values for the extinction of about 0.18 $\mathrm{km}^{-1}$ for $355 \mathrm{~nm}$ and $0.1 \mathrm{~km}^{-1}$ for $532 \mathrm{~nm}$ were observed in layers at altitudes 1.5 and $5.5 \mathrm{~km}$. At the same time the backscatter coefficient was lower in the highest layer than in the lowest one and reached 0.003 and $0.002 \mathrm{~km}^{-1} \mathrm{sr}^{-1}$ at $532 \mathrm{~nm}$, respectively, for lowermost and uppermost layer. For $355 \mathrm{~nm}$ backscatter coefficient values were 0.0015 and $0.0008 \mathrm{~km}^{-1} \mathrm{sr}^{-1}$, respectively.

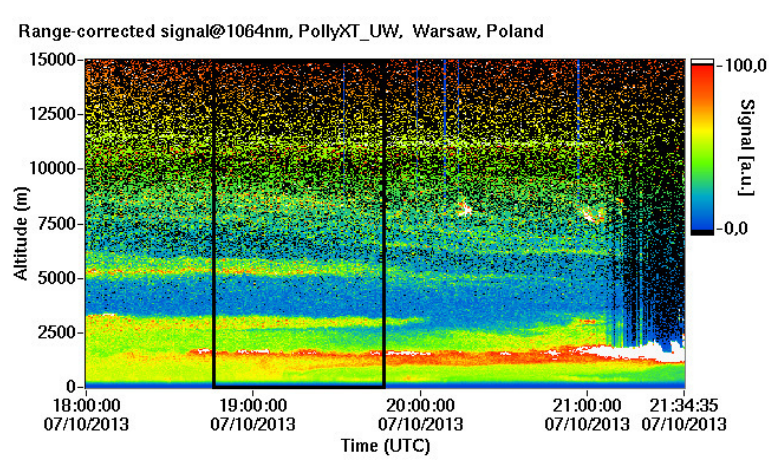

Figure 1. Range-corrected signal at $1064 \mathrm{~nm}$ between 18:00UTC and 21:34UTC on 10 July 2013. The black rectangle indicates the period chosen for the data analysis.

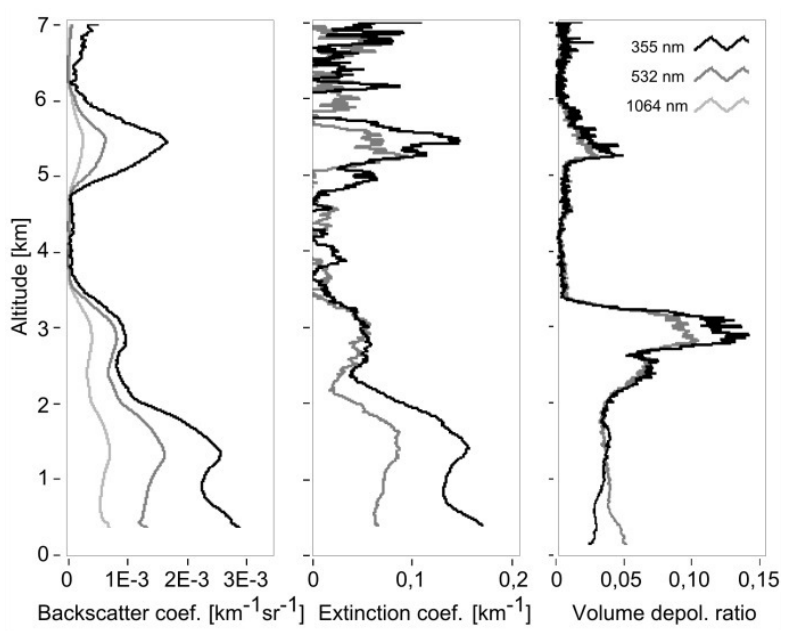

Figure 2. Vertical profiles of particle backscatter coefficient, particle extinction coefficient, linear volume depolarization ratio on 10 July 2013, averaged over 18:45UTC to $19: 45 U T C$.

The aerosol layer that was located at $3 \mathrm{~km}$ strongly differed from that at $5.5 \mathrm{~km}$. Here the backscatter and extinction coefficients values for 355 and $532 \mathrm{~nm}$ are very similar to each other, which is in contrast to the upper layer where 
values for $355 \mathrm{~nm}$ are larger. Backscatter and extinction coefficients for $532 \mathrm{~nm}$ did not vary very much between the layers $5.5 \mathrm{~km}$ and $3 \mathrm{~km}$. However, coefficients for $355 \mathrm{~nm}$ are significantly higher for the upper layer. It can be concluded that it is more likely that in the top layer strongly absorbing particles characteristic for the biomass burning aerosols could be present but the lower layer had rather different origin. This hypothesis is also confirmed by the profile of volume depolarization ratio shown in Fig. 2. The high values of about $15 \%$ for $355 \mathrm{~nm}$ and $10 \%$ for 532 $\mathrm{nm}$ were observed at an altitude of $3 \mathrm{~km}$. At a height of $5.5 \mathrm{~km}$ the depolarization ratio was less than $5 \%$ for both wavelengths. A low depolarization is characteristic for aged biomass burning aerosol [11], [12]. Relatively high values of depolarization can indicate mineral dust particles [13]. Given in Fig. 3, twelve-days HYSPLIT backward trajectories suggest that air masses incoming at $3 \mathrm{~km}$ could origin from Sahara. The trajectory ending at $5 \mathrm{~km}$ shows advection of biomass burning aerosol from Canada which is about six days old.

NOAA HYSPLIT MODEL

Backward trajectories ending at 1900 UTC $10 \mathrm{Jul} 13$ GDAS Meteorological Data

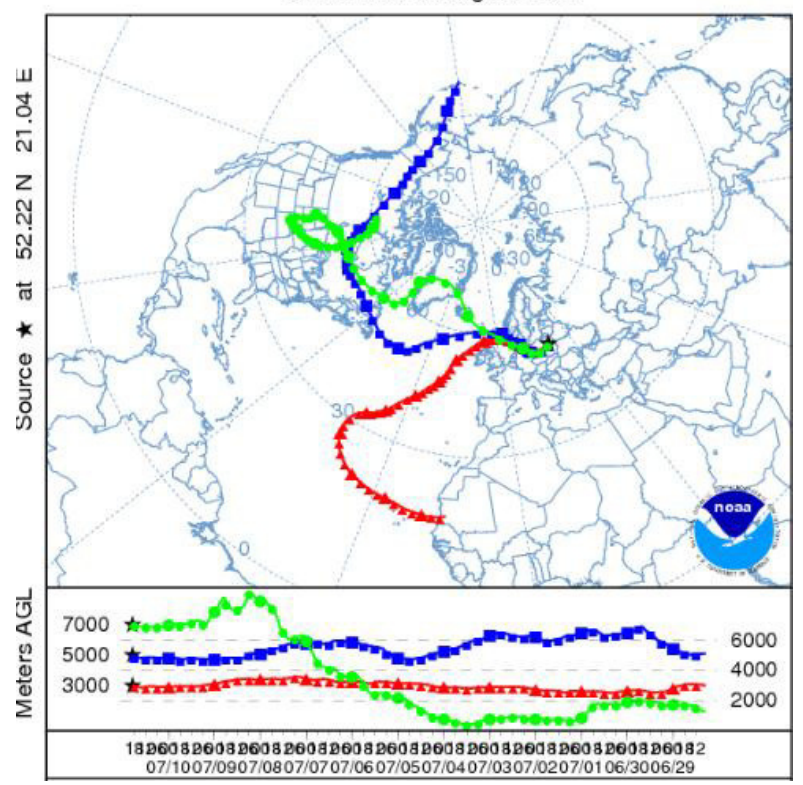

Figure 3. Twelve-days backward trajectories obtained by means of the HYSPLIT model arriving at Warsaw on $10^{\text {th }}$ July 2013.
The mean lidar ratio (not shown here) for this two layers is about 55 and $75 \mathrm{sr}$ for $355 \mathrm{~nm}$ and 70 and $95 \mathrm{sr}$ for $532 \mathrm{~nm}$ at $3 \mathrm{~km}$ and $5.5 \mathrm{~km}$ height, respectively. This values are consistent with lidar ratio values found during SAMUM campaign [13]. Lidar ratios at $532 \mathrm{~nm}$ are larger than the ones at $355 \mathrm{~nm}$. This property was noticed for aged biomass burning aerosols [14]. The mean color ratio $\beta(532 / 1064)$ was about 1.3 at both layers. The mean color ratio $\beta(355 / 532)$ at height $3 \mathrm{~km}$ was lower and reached about 0.5 , in the opposite of the upper layer, where this value was about 2 and was higher than $\beta(532 / 1064)$. The Ångström exponent for extinction at $3 \mathrm{~km}$ was below 0.5 which means large aerosol particle size.

\section{CONCLUSIONS}

The new Polly ${ }^{\mathrm{XT}}$ lidar operating at RT-Lab in Warsaw since June 2013 allowed for the detection of biomass burning aerosols incoming over Europe from Canadian wildfires in July 2013. Profiles of particle backscatter and particle extinction coefficients retrieved from one hour measurements from 18:45 UTC on 10 July 2013 showed, next to the boundary layer at about 1.5 $\mathrm{km}$, two distinct layers of aerosol at 3 and $5.5 \mathrm{~km}$. Wavelength independent backscatter and extinction coefficients were observed in the lower one, whereas in the upper one this properties highly depended on wavelength. High extinction, especially for $355 \mathrm{~nm}$, and low depolarization was observed in the top layer. It can be inferred that layer at $5.5 \mathrm{~km}$ contained biomass burning aerosols. The high lidar ratios obtained in this layer also confirm this hypothesis. However, the color ratio $\beta(355 / 532)$ for this layer was high, what is not typical for aged biomass burning aerosol where aging processes lead to increased particle size.

The HYSPLIT backward trajectories and high volume depolarization ratio indicate that lower layer of $3 \mathrm{~km}$ can include mineral dust particles from Sahara. Advection of Saharan dust particles over Warsaw is not unusual (another recent example of such event is discussed in [15]), however they occur most frequently in May and June. 


\section{ACKNOWLEDGEMENTS}

Part of the research was done within the SONATA BIS Project "Integrated study of climate processes involving absorbing aerosols" funded by NCN, Poland (Grant No. 2012/05/E/ST10/01578).

The lidar development was financed by FNITP, Poland (Grant No.519/FNITP/115/2010).

We acknowledge the NOAA Air Resources Laboratory (ARL) for the provision of the HYSPLIT transport model (http://www.arl.noaa.gov/ready.php) used for the interpretation for the results obtained in this publication.

\section{REFERENCES}

[1] Reid, J.S., R. Koppmann, T.F. Eck, D.P. Eleuterio, 2005: A review of biomass burning emissions part ii: intensive physical properties of biomass burning particles, Atmospheric Chemistry and Physics, 5, pp. 799-825.

[2] Althausen et al. 2009: Portable Raman Lidar Polly $^{X T}$ for Automated Profiling of Aerosol Backscatter, Extinction, and Depolarization. $J$. Atmos. Oceanic Technol., 26, 2366-2378.

[3] Draxler, R.R. and Rolph, G.D., 2012, HYSPLIT (Hybrid Single-Particle Lagrangian Integrated Trajectory) Model access via NOAA ARL READY Website (http://ready.arl.noaa.gov/HYSPLIT.php). NOAA Air Resources Laboratory, Silver Spring, MD

[4] Pappalardo, et al., 2014: EARLINET towards an advanced sustainable European aerosol lidar network, Atmos. Meas. Tech., 7, 2389-2409.

[5] Ansmann A., Riebesell M., and C. Weitkamp, 1990: Measurement of atmospheric aerosol extinction profiles with a Raman lidar, Opt. Lett., 15(13), 746-748.

[6] Klett, J. D., 1981: Stable analytical inversion solution for processing lidar returns. Appl. Opt., 20, 211-220.

[7] Fernald, F. G., 1984: Analysis of atmospheric lidar observations: Some comments. Appl. Opt., 23, 652-653.
[8] Freudenthaler, V., et al., 2009: Depolarization ratio profiling at several wavelengths in pure Saharan dust during SAMUM 2006, Tellus B, 61(1), 165-179.

[9] Veselovskii, I., Kolgotin, A., Griaznov, V., Muller, D., Wandinger, U., and Whiteman, D.N., 2002: Inversion with regularization for the retrieval of tropospheric aerosol parameters from multiwavelength lidar sounding, Appl Optics 41(18), 3685-3699.

[10] Chiliński M.T. et al., 2014: Study of Aerosol Radiative Properties During Long-range Transport of Biomass Burning from Canada to Central Europe in July 2013, $14^{\text {th }}$ Conference on Atmospheric Radiation, conference poster, https://ams.confex.com/ams/14CLOUD14ATRA D/webprogram/Paper250309.html

[11] Baars, H., et al., 2012: Aerosol profiling with lidar in the Amazon Basin during the wet and dry season, Journal of Geophysical Research, 117, D21201, doi:10.1029/2012JD018338.

[12] Nicolae D. et al. 2012: Change of Optical and Microphysical Properties of Biomass Burning Aerosol During Transport in the Free Troposphere, Reviewed and Revised Papers $26^{\text {th }}$ International Laser Radar Conference, 463-466.

[13] Groß, S., et al., 2011: Characterization of Saharan dust, marine aerosols and mixtures of biomass-burning aerosols and dust by means of multi-wavelength depolarization Raman lidar measurements during SAMUM 2. Tellus B, 63, pp. 706-724.

[14] Muller D., et al, 2005: Raman lidar observations of aged Siberian and Canadian forest fire smoke in the free troposphere over Germany in 2003: Microphysical particle characterization, Journal of Geophysical Research, 110, D17201.

[15] Costa-Surós M., I.S. Stachlewska, A. Nemuc, C. Talianu, B. Heese, and R. Engelmann, 2015: Study case of air-mass modification over Poland and Romania observed by the means of multiwavelength Raman depolarization lidars, International Laser Radar Conference (ILRC 27th), 5-10 July 2015, New York, USA, Paper ID: 315 . 